\title{
Model of Empowerment as Strategies for Women SMEs Entrepreneurs Competitiveness in Palembang
}

\author{
Fetty Maretha ${ }^{1, *}$, Yulia Pebrianti ${ }^{1}$, Rini $^{1}$, Lisnini $^{1}$ \\ ${ }^{1}$ Business Administration, State Polytechnic of Sriwijaya and State, Palembang, Indonesia \\ "Corresponding author Email: fetty@polsri.ac.id
}

\begin{abstract}
This research is aimed to find out how empowerment through targeted programs in increasing the competitiveness of women SMEs entrepreneurs in Palembang. This study uses data consisted of 325 Woman SME population units in Palembang. The sample used in this study was 179 respondents. The model used for this study is a percentage of the respondent's answers with an index score. The results showed that the variable capital and human resources quite influential on competitiveness. The Production variable has a strong influence on competitiveness. Managerial variables have weak or no effect on competitiveness. Information Technology and Market Variables have quite an effect on competitiveness. Women SMEs entrepreneurs in Palembang have interpretations of competitiveness scores that are quite good.
\end{abstract}

Keywords: empowerment, competitiveness

\section{INTRODUCTION}

SMEs in economic growth have an important and strategic role in economic growth, not only in developing countries like Indonesia but also in developed countries as well. In Indonesia, SMEs have a role not only to participate in economic growth but also has a very important role in overcoming an unemployment problem. Growing and developing small and medium-sized businesses have an opportunity for economic growth, the chance of employment and community welfare. It is important to realize that SMEs have the role to empower SMEs in the framework of accelerating regional economic development and the center for increasing the competitiveness of SMEs. According to the Deputy Governor of Bank Indonesia [1] women has an important role in economic activities, especially in micro, small and medium enterprises (MSMEs). His data shows the contribution of women entrepreneurs to Indonesia's GDP has only increased by 9.1\% while the contribution to exports is still below 5\%. There is still space to encourage the role of women in the economy. In terms of ownership, SMEs account for $51 \%$ of small entrepreneurs and $34 \%$ of medium-sized businesses owned by women. World bank data in 2016 shows the ratio of female business ownership in Indonesia is higher than in the world, especially at SMEs (Rosmaya, 2017). Empowerment of Micro, Small and Medium Enterprises (MSMEs) has become an important issue as a driving force for economic growth and improvement in many countries in the world. Good dynamics and economic performance with high growth rates in many countries is the performance of the national economy supported by the SMEs that are efficient, productive, and highly competitive. In other parts of the world, SMEs (Small and Medium-sized Enterprises (SMEs) play a very significant role in the growth and development of a country's national economy. To improve the competitiveness, the cooperation between government and supporting institutions are needed, especially microfinance institutions to make easier access to credit and the expansion of marketing information networks. And also the action of using national product needs to expand to help the national economy becomes stronger. Micro, small and medium business owner need to be more active to collaborate and coordinate with the Government and Regional Governments to continue to provide guidance and training through capacity building and information technology (IT) applications, including re-effectiveness of the current local government web that is not yet optimal as SMEs based communication in the region. The problems SMEs have are limited business capital, difficulties in marketing, fierce business competition, difficulties in raw materials, lack of technical production and expertise, less managerial skills, lack of financial management knowledge, and a less conducive business climate. Although the number of SMEs businesses in Palembang are very large, training and coaching programs especially in empowering SME owners have not been maximized. Based on the problems faced by SMEs, the researchers are interested in choosing "Model of Empowerment as a Strategy for Women SMEs Entrepreneurs Competitiveness in Palembang" as the title.

\section{LITERATURE REVIEW}

According to Ni Nyoman Sunariani et al. [2], empowerment is an effort to build power (community) by encouraging, motivating, and raising awareness of its potential. The empowerment of a people's economy must be carried out by the government in collaboration with non-governmental organizations and the bank. There are five main missions in empowerment (1) awareness; (2) 
organizing; (3) companion cadre; (4) technical support, and (5) system management. Based UU No. 20 the year 2008 [3], SMEs empowerment is an effort that becomes the responsibility of the government, regional government, and the community to grow and develop so that SMEs will remain resilient and independent. The approach that provides subsidized credit and low interest have shifted to an approach that focuses on more training activities for bank officers, research and information provision [4].

According to the results of a study by BI and Unud (2011), the problems that are often faced include market access, business financing, low ability of production techniques and quality control, management in general [5].

Human resources (HR) are the main assets for an organization or agency because they are the driving force of an organization. Therefore, it requires human resources who are knowledgeable, high-quality capacity and competitiveness so that they will be able to develop and maintain the position of the organization/agency in a competitive environment.

Information Technology is a form of technology that used to create, store, change and use the information in all its forms [6]. Through the use of information technology, micro, small and medium enterprises can enter the global market. IT makes it easier for SMEs to expand markets both domestically and internationally with time and costefficient. With the existence of IT-based SMEs, we can compete in terms of quality, packaging, and marketing.

Mmanagerial aspects [7], are increasing productivity (turnover/utility level/occupancy rate/increasing marketing capabilities, and human resource development).

Capital is economic resources created by humans in the form of value for money or goods. Capital in the form of money can be used by the production to buy new goods for the sector. Another kind of capital for a business is credit. Credit is money or bills agreement between the bank and another party that requires the borrower to repay the debt after a certain period with interest [8]. Capital aspects include; capital assistance (allowance for 1-5\% of BUMN profits and the obligation to distribute a minimum loan of $20 \%$ of the bank loan portfolio) and credit facilities (KUPEDE, KUK, KIK, KCK, mini/midi credit, KKU).

Tambunan (2008) [9] said that the competitiveness of a company is reflected in the competitiveness of the products it is produced and it can be characterized by internal and external factors. These internal factors include (1) expertise or education level of workers, (2) employer's expertise, (3) availability or access to capital, (4) good organizational and management systems (according to business needs), (5) availability or technological mastery, (6) availability or information mastery, and (7) availability or control / access to other inputs such as energies, raw materials, and others.

Competitiveness is productivity that is defined as output produced by labor. According to the World Economic Forum, national competitiveness is the ability of the national economy to achieve high and sustainable economic growth. Competitiveness is determined by the competitive advantage of a company and is very dependent on the level of its relative resources or it often called competitive advantage.

Porter explained the importance of competitiveness are because of these three things: (1) encouraging productivity and increasing self-sufficiency, (2) increasing economic capacity, both in the context of regional economies and the number of economic owners so that economic growth increases, (3) believing that market mechanisms create more efficiency.

\subsection{Framework}

According to the literature review and previous research that has been explained before, it can be shown in a theoretical framework regarding the effect of variable $\mathrm{X}$ used in this study to Variable Y, shows in Figure 1:

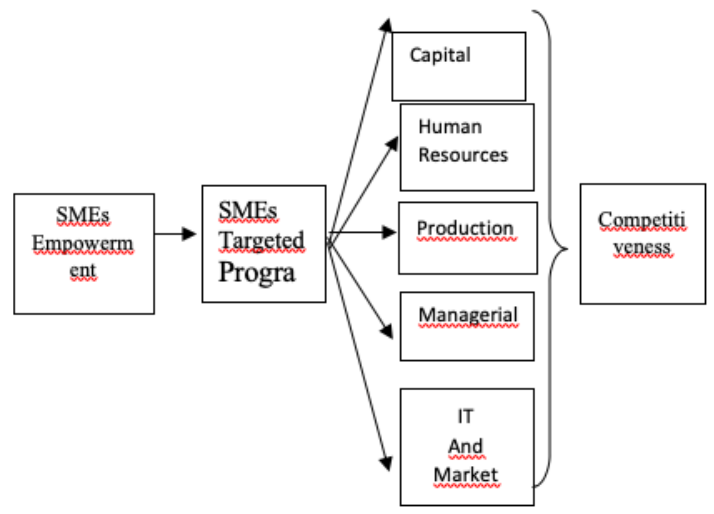

Figure 1 Framework

From the results of the framework above empowering SMEs through targeted programs in the areas of the capital, human resources, production, managerial and information technology (IT) and the market can increase competitiveness.

\subsection{Population and Sample}

Population [10] is a generalization area consisting of objects/subjects that have certain qualities and characteristics determined by researchers to be studied and then make conclusions. The population in this study was 325 units. A sample is part of the number and characteristics owned by the population [10]. The sample used in this study was 179 respondents.

\subsection{Score and Index Model}

The model that has been used for this study is a presentation of the respondent's answers. To see the percentage of respondent's answers to the questions in the questionnaire, the Score Index (IS) formula is being used. 
According to Ridwan, 2006 [11], the formula for calculating the Index Score is:

$$
\text { IS }=\left(\frac{\text { Total Research Score }}{\text { Ideal score }} \times 100 \%\right)
$$

The score interpretations are represented in Table 1:

Table 1 Score Interpretations

\begin{tabular}{|c|c|c|}
\hline No & Score (\%) & Interpretation \\
\hline 1 & $0-20$ & Very Weak \\
\hline 2 & $21-40$ & Weak \\
\hline 3 & $41-60$ & Enough \\
\hline 4 & $61-80$ & Strong \\
\hline 5 & $81-100$ & Very Strong \\
\hline
\end{tabular}

The ideal score $=4$ (highest scale) $\mathrm{x}$ number of respondents.

\section{DISCUSSION}

\subsection{Capital variable as a strategy for women SMEs entrepreneurs competitiveness in Palembang}

Based on the results of the questionnaire for the first statement, the variable Capital appears "Enough" with $55.68 \%$. This shows that capital for women entrepreneurs provides an adequate response to increasing competitiveness. Capital is economic resources created by humans in the form of value for money or goods. Capital in the form of money can be used by the production to buy new goods for the sector. Another kind of capital for a business is credit. Credit is used for providing money or payments based on approval between banks and other parties that require the borrower to repay the debt after a certain period with interest.

\subsection{Human resources variable as a strategy for women SMEs entrepreneurs competitiveness in Palembang}

Based on the results of the questionnaire, the human resource variable appears "enough" with $44.95 \%$. This shows that Human Resources provides a response that is quite influential in increasing the competitiveness of women entrepreneurs in Palembang.

Human resources (HR) are the main assets for an organization or agency because they are the driving force of an organization. Therefore, it requires human resources who are knowledgeable, high-quality capacity and competitiveness so that they will be able to Although the number of SMEs businesses in Palembang is very large, there is still a need for training and coaching programs especially in empowering SMEs owner or human resources that haven't been maximized to increase competitiveness.

\subsection{Production variable as a strategy for women SMEs entrepreneurs competitiveness in Palembang}

Based on the results of the questionnaire, the Production variable appears "strong" with $73.29 \%$. This shows that the production gave a strong effect on increasing the competitiveness of women SMEs entrepreneurs in Palembang. Production is an activity that is done to add value to an object or create new objects so that it is more useful in needs. Production is not only raw mater but also storage, distribution, retailing, and repackaging and others.

\subsection{Managerial variable as a strategy for women SMEs entrepreneurs competitiveness in Palembang}

Based on the results of the questionnaire, the Managerial Variable appears "Weak" with 37,89\%. This shows that production gave a weak effect on increasing the competitiveness of women SMEs entrepreneurs in Palembang. Managerial aspects are including, increasing productivity/turnover/utility/levels/occupancy rates / increasing marketing capabilities and human resource development. From this research, it can be known that the managerial ability of women SMEs entrepreneurs in Palembang is still weak.

\subsection{IT and market variables as a strategy for women SMEs entrepreneurs competitiveness in Palembang}

Based on the results of the questionnaire, the Information Technology and Market variables appear "enough" with $47.44 \%$. This shows that the production response is quite influential in increasing the competitiveness of SME women entrepreneurs in Palembang. To dominate the market, SMEs need to get information easily and quickly, both information about the production market and factor market production to expand the marketing network of products produced by SMEs. The application of information technology to micro, small and medium businesses will facilitate SMEs to expand markets both domestically and overseas markets efficiently. The establishment of an IT-based MSME Development Center is considered capable of encouraging the growth and development of micro, small and medium businesses in the current era of information technology. 


\subsection{Strategies for women SMEs entrepreneurs competitiveness in Palembang}

Based on the results of the questionnaire, the Competitiveness variable appears "enough" with $55.11 \%$. This shows that the competitiveness of women SMEs entrepreneurs in Palembang is quite good. The competitiveness of a company is reflected in the competitiveness of the products it's produced and it can be characterized by internal and external factors.

\section{CONCLUSION}

Based on the results of the research on "Model of Empowerment as a Strategies for Women SMEs Entrepreneurs Competitiveness in Palembang" shows that capital variable and human resources quite influential on competitiveness. Production Variable has a strong influence on competitiveness. Managerial variables have little or no effect on competitiveness. Information Technology and Market Variables have quite an effect on competitiveness. Women SMEs entrepreneurs in Palembang scores have interpretations of competitiveness that are quite good.

\section{REFERENCES}

[1] Akdon, and Ridwan, Statistical Applications and Research methods for Administration and Management. Bandung: Dewa Ruci, 2006.

[2] Bank Indonesia, Economic and Financial Studies. Quarter II. Bali Province, 2015.

[3] Bank BRI Denpasar In collaboration with Denpasar National Education University, Denpasar Regional Economic Study and Badung Regency in Bali Province, 2016.

[4] Kotler, Philip and Gary Armstrong. 2009, Principles of Marketing. Erlangga, Jakarta, Indonesia, 2009.

[5] Mudrajat Kuncoro, Indonesian Industrial Economy, Andi Offset. Yogyakarta, 2007.

[6] Setyobudi, Andang, "The Participation of Bank Indonesia in the Development of Micro, Small and Medium Enterprises", MSME Bulletin of Banking and Banking Law. Volume 5, Number 2, pages 2935, August 2007.

[7] Business and management. Indonesia Volume 2, Number 1, December, 2018.

[8]Sukesi and Sugiyanto. "Work Relationships and Gender Relations Dynamics in the People's Sugar
Cane Enterprise System", Institute of Agriculture Faculty Publishing. Malang Brawijaya University, 2002.

[9] Sedyastuti Kristina, "Analysis of Empowerment of MSMEs and Increasing Competitiveness in the Global Market Scene". Indonesian Journal of Business Innovation and Management Volume 2, Number 1, December, 2018.

[10] Sunariani Ni Nyoman, et al. "Empowerment of Micro and Small and Medium Enterprises (MSMEs) through the Fostered Program in Bali Provision", Scientific Journal of Management and Business Vol. 2 No.1, 2017.

[11] Tambunan, sincere, Small and medium micro businesses in Indonesia: Important issues. LP3ES. Jakarta, 2008.

[12] Republic of Indonesia Law No. 20 of 2008. About Micro, Small and Medium Enterprises. 